\title{
EFFECT OF COLD STORAGE CONDITIONS ON PHYSICAL PROPERTIES OF POTATO TUBERS
}

\author{
Darwesh, M. and Elmetwalli, A. H.
}

\begin{abstract}
Post harvest processes of potato tubers are crucially important to keep crop losses at a minimum. Besides stacks dimensions, arrangement of potato stacks within commercial cold stores is one of the main reasons causing storage losses and low potato tubers quality. This research attempted to investigate the influence of storage duration and stacks height on physical properties of two potato varieties (Diamont and Invootar). The cold store was kept at $4-10{ }^{\circ} \mathrm{C}$ and $65-70 \%$ relative humidity. The results showed that the change rate in length, width and thickness was higher in diamond variety more than Invootar variety at all investigated stacks height. Surface area of potato tubers increased with increasing stacks height and decreased with storage duration. Temperature within the stacks decreased with the treatments at 3 and $6 \mathrm{~m}$ stack height that improved potato quality parameters. The results therefore revealed that selecting the optimum potato stacks height can improve the movement of air through stacks and also improve heat transfer within the stack.
\end{abstract}

Key words: potato, tubers, stack, height, physical, properties, storage

\section{INTRODUCTION}

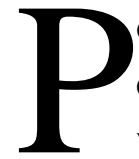
otato (Solanum tuberosum L.) is the fourth most important food crop after wheat, rice and corn. The crop is grown throughout the world with a production of about 320 million tons fresh tubers. The estimated cultivated area is about 20 million hectare worldwide. In Egypt, potato is usually kept in commercial cold stores after harvesting operation from May to December in a temperature range of $4-10^{\circ} \mathrm{C}$. The purpose of potato storage is to provide local market by potato crop from May to December period. In addition, this operation covering farmer's requirements from potato to plant it in a suitable time. Pardo et al. (2000) indicated that the quality of potatoes is a combination of various physiochemical and nutritional characteristics, which are greatly influenced by storage conditions.

Assis. Prof., Agric. Eng. Dept., Fac. of Agric., Tanta Univ., Egypt 
Fresh horticultural and agricultural crops are living organisms. They must be remained alive and healthy until processed or consumed. Energy needed for these life processes comes from the accumulated food reserves through a process called respiration. The final result of respiration activity leads to product deterioration and senescence, and hence achieving as low respiration rate as possible very important to prolong the shelf life of biological materials (Brosnan and Sun ,2001). Chourasia and Goswami (2001) pointed out that low-temperature storage can cause freezing injuries which cause tubers to become soft and unusable. However, high storage temperature produces greater quality loss and increases respiration activity and thus lowered shelf life. Nourian et al. (2003) stated that appropriate storage environment should maintain tubers in their edible and marketable conditions by preventing large moisture losses, spoilage by pathogens, quality deterioration and sprout growth. Therefore, cold storage may provide the necessary environment to prevent weight loss, shrinkage and shape marketable of potato tubers. Verboven et al. (2006) determined many factors that affect the respiration rate such as commodity, variety, maturity or ripeness stage, injuries, temperature, gas conditions and other stress related factors. During cooling process of agricultural crops particularly potato cooling conditions should be controlled carefully especially with respect to air temperature and humidity (Hoang et al., 2004). The optimum range of temperature and relative humidity of the air inside cold stores are $2-4{ }^{\circ} \mathrm{C}$ and $85-90 \%$ respectively for long term storage (Van't Oostar, 1999). However, previous studies showed large variation in temperature and relative humidity in cold stores ranging from $2-5{ }^{\circ} \mathrm{C}$ and $80-92 \%$ respectively. Moreover, excessive dehydration of products should be avoided to reduce quality loss as well as loss of saleable weight. Potato is usually put in cold stores in gunny bags and arranged in bulks or stacks. Chourasia and Goswami $\left(\mathbf{2 0 0 7}_{\mathbf{b}}\right)$ pointed out that gunny bags are made of woven jute threads and allow the exchange of air and moisture rather than heat between the surrounding air between the product. However, when such bags are placed on a floor or any other hard surface, the bag bottom becomes impermeable. Chourasia and Goswami (2007b) found that uniform cooling through a bulk of potatoes in commercial cold stores 
is difficult to attain, owing to existence of an uneven distribution of airflow, which results in remarkable temperature, and humidity differences within the stored product. The impermeable bottom decreases airflow rate between potato gaps, consequently causing difficulty to have uniform temperature in this vertical gap. It is therefore important to provide good environment which affect potato properties. The aim of this research was to investigate the effect of stacks height and storage duration on some potato properties such as basic dimensions, mass moisture loss and temperature distribution throughout vertical stacks.

\section{MATERIALS AND METHODS}

The experimental work of the present study was undertaken in a private commercials potato cold store in Denosher village, Elmehala Elkobra, Gharia province, Egypt (latitude of $30.95^{\circ} \mathrm{N}$ and longitude of $31.09{ }^{\circ} \mathrm{E}$ ) during 2014.

\section{Potato variety}

Potatoes are normally brought into cold stores in June and July to December. Diamont and invootar are the two most widely cultivated potato cultivars in the Nile Delta region. Diamont variety is a healthy and strong crop with very high marketable yields, as well as high moderately resistant to bruising. Its yellowed-skinned and tubers are large size, oval and uniform in shape. Its tubers also have excellent storing ability. Invootar variety is large, long-oval, with reddish yellow and fairly good resistance to internal bruising.

\section{Commercial cold store}

The cross-sectional view of commercial potato cold store is shown in Fig. 1. In a typical commercial cold store, the product is packed in gunny bags, made of meshed jute threads, and these bags are arranged in the form of rectangular stacks in cold storages. The cold store consists of two floors separated by wooden planks and is served mainly by a vapor compression refrigeration system. A direct expansion (TXE5) type of evaporator was used. The cooling coils of the evaporator are made of bare tubes or may sometimes have square shaped fins. A drain pan made of concrete was placed below the cooling coils to collect defrosted water. The size of a single potato stack in commercial cold store is usually $3 \mathrm{~m}$ 
height, $3.5 \mathrm{~m}$ width and $11 \mathrm{~m}$ length. Such stacks are usually placed on wooden planks one above another with $0.2 \mathrm{~m}$ vertical gap. In this manner, there were 8-10 stacks in the vertical direction. This is called the column of the stacks. A commercial cold store has 2-4 such columns of stacks.

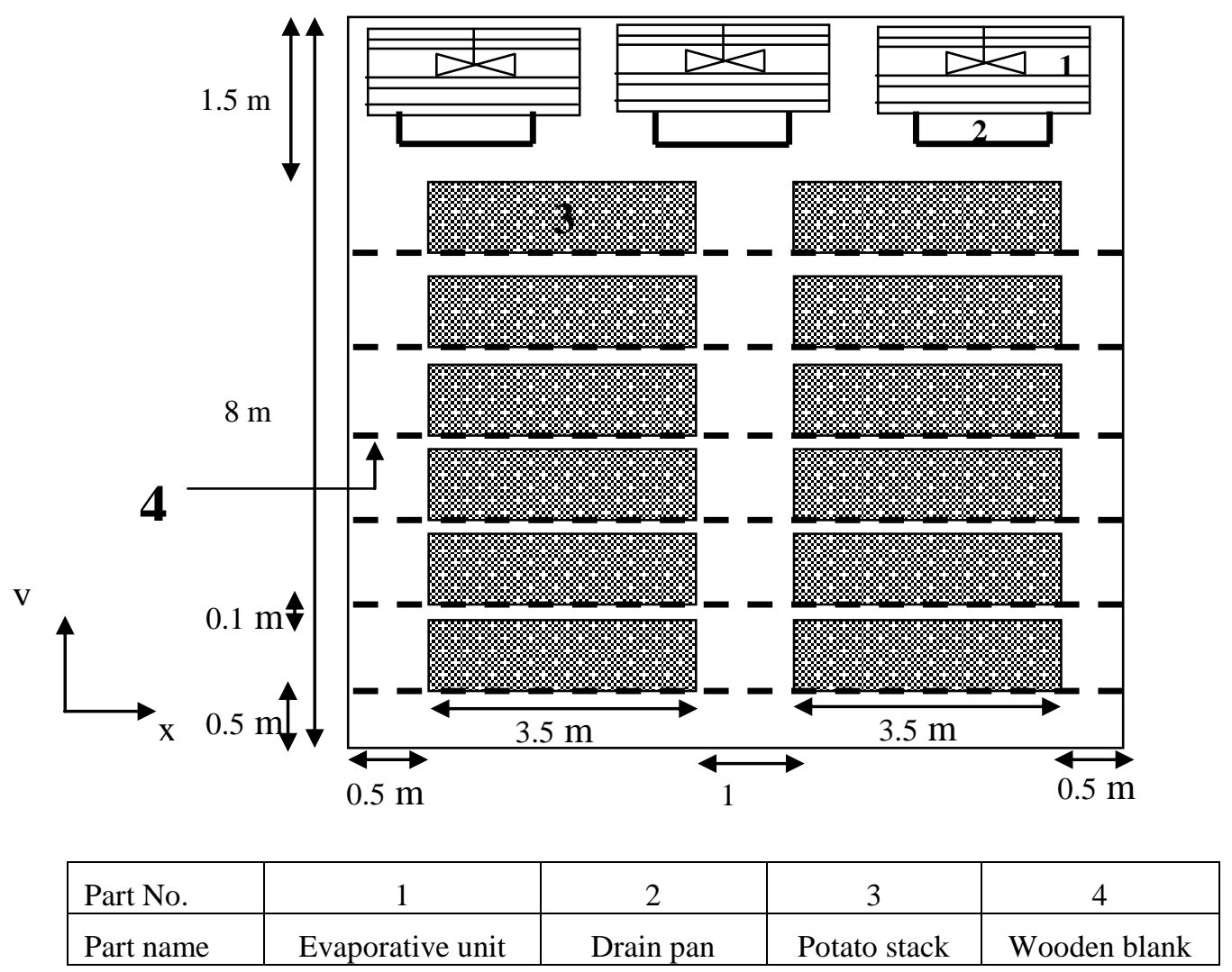

Fig. 1 Cross sectional view of a typical commercial potato cold store

\section{Instruments}

- Mass of individual potato was determined using a digital scale with an accuracy of $0.1 \mathrm{~g}$.

- A digital slide caliper of $0.01 \mathrm{~mm}$ accuracy was used for measuring the three basic dimensions (basic axes; length, width and thickness) of tubers.

- A data logger having eight channels was used to record temperatures at different locations. The used data logger has a keyboard, a monitor, a programmed card and controllers. 


\section{Methods}

Fresh harvested potatoes of both investigated varieties were brought to the cold store and were prepared 4 days after harvest. Prior to storage, potatoes were cleaned with a soft brush to remove the adhering soil and other foreign materials. The cleaned potatoes were put in bags, kept at room temperature (22 to $25^{\circ} \mathrm{C}$ ) for one week to heal cuts and then stored at a temperature ranged between $4-10^{\circ} \mathrm{C}$ and relative humidity of 65 $70 \% .35$ potato tubers from each cultivar for each treatment were firstly selected randomly and then coded to investigate physical characteristics of potato every 15 days recording interval (a total test of 8 weeks). Potato stacks were put at three different heights 0,3 and $6 \mathrm{~m}$.

The geometric mean diameter $(\mathrm{Dp}, \mathrm{mm})$ and surface area $(A)$ were calculated according to Golmohammadi and Afkari-Sayyah (2013) as follows:

$$
\mathrm{Dp}=(\mathbf{L W T})^{1 / 3}
$$

The surface area $\left(\mathrm{A}, \mathrm{cm}^{2}\right)$ was determined using Polya's equation as follows:

$$
\mathrm{A}=4 \text { (Ac) }
$$

Where, $\mathrm{Ac}$ is in $\mathrm{cm}^{2}$ and can be calculated using the following equation

$$
\text { Ac }=\mathbf{K}(\mathbf{V})^{2 / 3}
$$

Where, $V$ is the theoretical volume of the tuber $\left(\mathrm{cm}^{3}\right)$ and $\mathrm{K}$ is a dimensionless constant

The theoretical volume was calculated according to Mohsenin (1986) using the following equation:

$$
\mathbf{V}=(\pi / 6)(\mathbf{L W T})
$$

In the present study, the value of $\mathrm{K}$ for Potatoes was taken 1.38 according to

The effective diameter $\left(D p, \mathrm{~cm}^{3} / \mathrm{cm}^{2}\right)$ was calculated according to Golmohammadi and Afkari-Sayyah (2013) can be calculated as:

$$
\mathrm{dp}=V / A
$$

\section{Moisture loss}

The loss in potato moisture was determined by weighing the tubers every 15 days and was calculated by the difference between weights at the beginning and end of each 15 days. Moisture loss percent was calculated as follows: 


$$
M C=\frac{W-D}{W} * 100
$$

Where; $\mathrm{MC}$ is the moisture content loss in $\%, \mathrm{~W}$ is the initial weight of tubers sample and $\mathrm{D}$ is the weight after 15 days for the same sample

\section{Temperature measurements}

The data-logger was connected with eight sensors (therimstors type) to measure the temperature at certain selected points. The respective locations of the temperature sensors embedded bags in the stack. Temperature was recorded every five minutes and data were updated by a scan of all the sensors every two second, and the mean of 600 scans was reached each on a computer. To plot the temperature data with time throughout the day it was averaged every hour to reduce variations within each hour.

The enthalpy source term was calculated according to Chourasia and Goswami (2007a) as follows:

$$
S_{f}^{h}=Q_{r}-\left(m_{w} h_{f g}\right)
$$

Where $\mathrm{m}_{\mathrm{w}}$ is the rate of moisture loss in $\mathrm{kg} / \mathrm{m}^{3}, \mathrm{~h}_{\mathrm{fg}}$ is the latent heat of evaporation in $\mathrm{J} / \mathrm{kg}$ which was calculated according to $\mathrm{Hu}$ and Sun, 2000 as follows:

$$
\mathrm{h}_{\mathrm{fg}}=2.5^{*} 10^{3}\left[10^{3}-(\mathrm{T}-273.15)\right]
$$

$\mathrm{Q}_{\mathrm{r}}$ is the rate of metabolic heat generation in $\mathrm{W} / \mathrm{m}^{3}$ which was calculated according to Van't Ooster (1999):

$$
Q r=\rho\left[\frac{\{0.08039(T-273.15)+14.303\}}{1000}\right], T>276.15 k
$$

Where $\mathrm{T}$ is the potato tuber's temperature in $\mathrm{K}$. is the density of potato which was taken $1100 \mathrm{~kg} / \mathrm{m}^{3}$.

The steady state rate of mass transfer under equilibrium conditions could be expressed as by Chourasia et al. (2005):

$$
\mathbf{m}_{\mathrm{w}}=\mathbf{k}_{\mathrm{m}} \mathbf{p}_{\mathrm{sat}}\left(\mathbf{a}_{\mathrm{w}}-\mathbf{R H} / \mathbf{1 0 0}\right) \mathbf{a}_{\mathrm{p}}
$$


Where $\mathrm{k}_{\mathrm{m}}$ is the overall mass transfer coefficient in $\mathrm{kg} / \mathrm{s} \mathrm{m}^{2} \mathrm{~Pa}$ and was taken $2.27 * 10^{-10}$ according to Chourasia et al., 2005

$\mathrm{p}_{\text {sat }}$ is the saturated vapor pressure in $\mathrm{Pa}$

$\mathrm{a}_{\mathrm{w}}$ is the water activity at the surface of the product and was taken 0.987 according to Chourasia and Goswami, 2007a

$a_{p}$ is the specific surface area in $\mathrm{m}^{2} / \mathrm{m}^{3}$ which was calculated according to Gean Koplis, 1993 using the following equation:

$$
\mathrm{a}_{\mathrm{p}}=6(1-\varepsilon) / \mathrm{dp}
$$

$\varepsilon$ is the porosity in the bag and was taken 0.4 and

$\mathrm{dp}$ is the effective diameter in $\mathrm{mm}$ and

$\mathrm{RH}$ is the relative humidity in the stack in \%,

\section{RESULTS AND DISCUSSIONS}

\section{Effects of potato stacks height and storage duration on potato tuber mass}

Fig.2 (a,b, and c) illustrates the effect of storage duration on mass of potato tubers for diamont and invootar potato varieties at different stacks heights throughout storage time. The logarithmic trend of potato tubers mass was found to be the optimum for depicting this relationship. Broadly, potato tubers mass tend to decrease with increasing storage period reaching the minimum at 60 days storage time. The figures show high variations between different height levels for both potato verities. The results also showed that the change rate of potato tuber mass for diamont variety was higher than in invootar variety at all stacks heights except at $0 \mathrm{~m}$. These results may have been a result of low ability of invootar variety to put at low height. Statistical logarithmic regression analysis was run on the experimental measured data to identify the effect of storage duration on mass of potato tubers at various stacks heights. The results of the regression analysis showed strong relationships between storage duration and tuber mass at all stacks height with high coefficient of determination values (>0.90) as shown in figures $\mathrm{a}, \mathrm{b}$ and $\mathrm{c}$. 

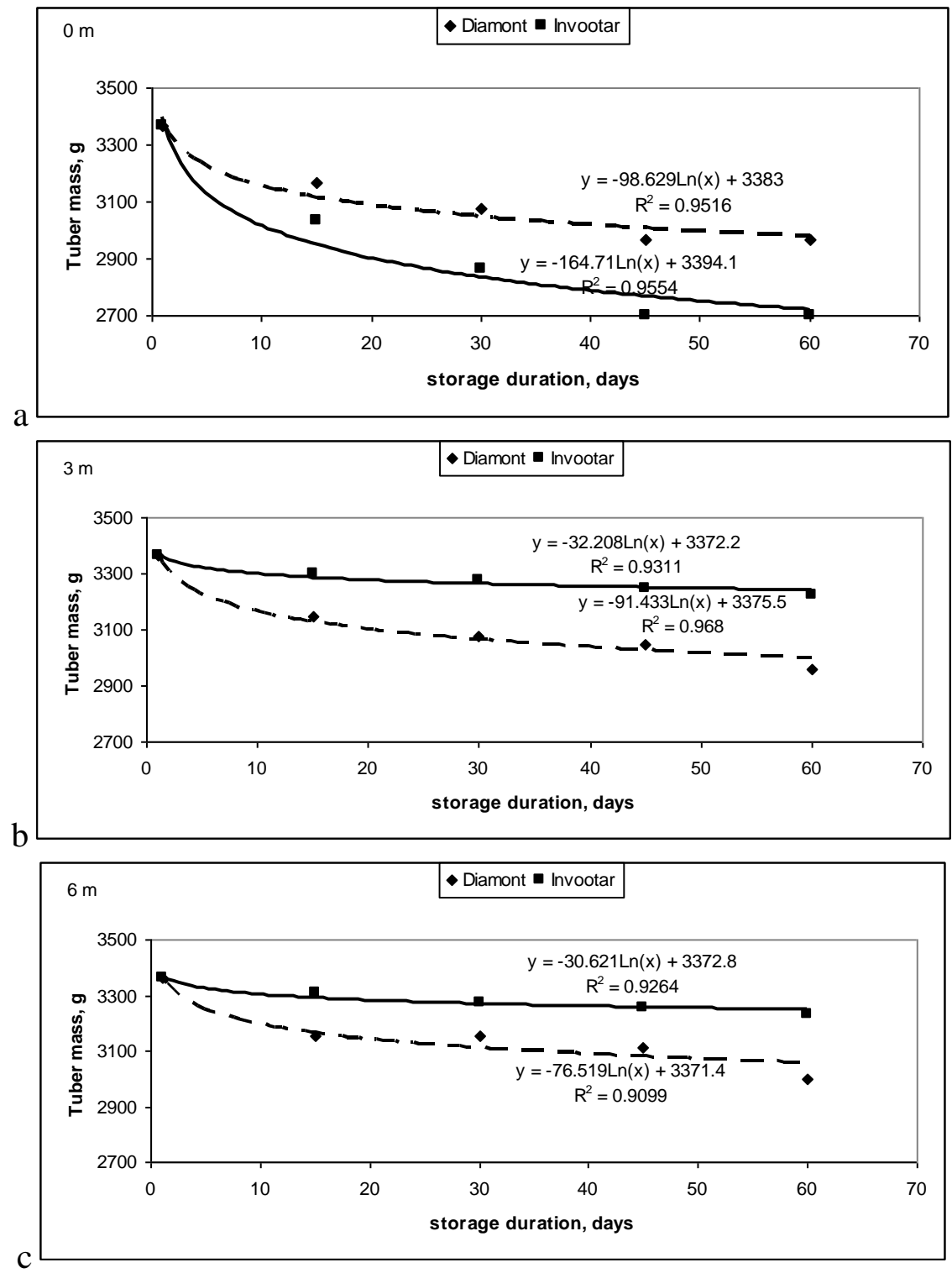

Fig.2 Effects of storage duration on potato tuber mass at various stacks heights (a) $0 \mathrm{~m}$, (b) $3 \mathrm{~m}$ and (c) $6 \mathrm{~m}$

\section{Effects of stacks height and storage duration on geometric mean diameter of potato tubers}

Fig. 3 depicts the effects of storage duration and potato stacks height on the geometric mean diameter. The obtained results for both investigated verities showed negative relationships between Dp and storage duration 
particularly at $3 \mathrm{~m}$ stacks height stacks height. The lowest geometric mean diameter of 43.4 and $44.3 \mathrm{~mm}$ for diamond and invootar was recorded at 60 days storage duration and $3 \mathrm{~m}$ stacks height The results demonstrated that $0 \mathrm{~m}$ produced the maximum geometric mean diameters at all storage durations. $6 \mathrm{~m}$ stacks heights have more or less the same effect of $0 \mathrm{~m}$ stack height on geometric mean diameter.

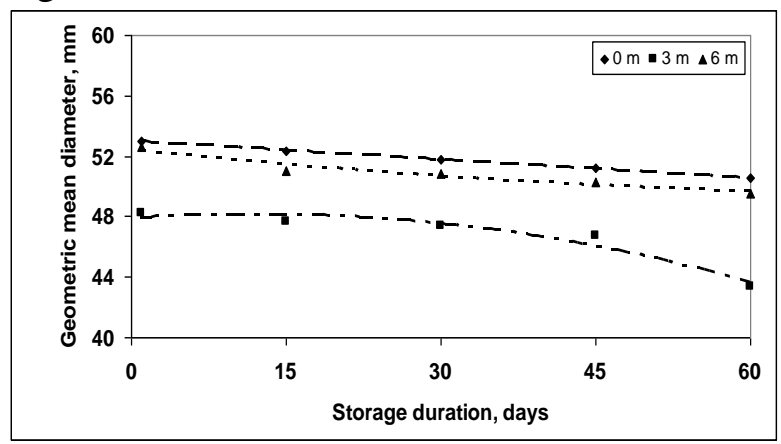

(a)

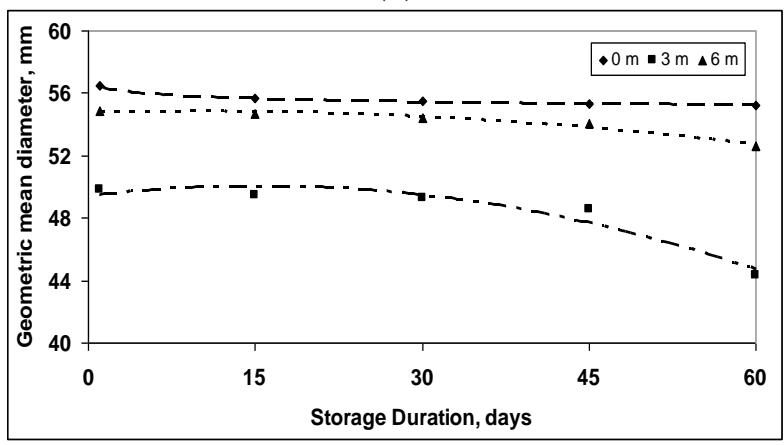

(b)

Fig. 3 Effect of storage duration on surface area of potato tubers for both diamond and invooter varieties at different stacks heights

Different potato physical properties as influenced by storage duration and stacks height

Due to enzymes activities and other biological processes over the time of storage, potato tubers change as a result of moisture loss associated with mass loss. The effects of stacks height on the change rate of length, width and thickness of potato varieties as revealed in Fig. 4. The results obviously demonstrated that $3 \mathrm{~m}$ stacks height reduced the change rate of all the three dimensions for both potato varieties. It is shown that invootar variety is less affected by stacks height in comparison to diamond variety. 
The regression analysis was performed to identify the relationship between different stacks height and the three basic potato dimensions. Regression equations were derived for the range of 0-6 m stacks height. Table 1 and table 2 detail different regression equations for the prediction of width, length and thickness of both investigated potato varieties (diamond and invootar). The results of regression equations showed higher coefficient of determination for different stacks heights ranging from 0.90 to 0.99 for both diamond and invooter. These results demonstrated that the basic potato dimensions can be predicted under certain storage conditions with respect to stacks height. Differentiation was also used to derive equations for the prediction of the change rate of basic dimensions. The comparison mainly depended on the values of the coefficient of determination $\left(\mathrm{R}^{2}\right)$.

Table 1: Regression equations derived for the relationship between storage duration (S) and potato basic dimensions of Invootar variety

\begin{tabular}{|l|l|l|l|l|}
\hline Height & Properties & Equation & $\mathbf{R}^{\mathbf{2}}$ & Change rate (dD/dt) \\
\hline \multirow{4}{*}{$\mathbf{0 ~ m}$} & mength & $\mathrm{L}=1 \mathrm{E}-05 \mathrm{~S}^{2}-0.02 \mathrm{~S}+83.8$ & 0.999 & $0.00002 \mathrm{~S}-0.02$ \\
\cline { 2 - 5 } & Width & $\mathrm{W}=-0.31 \mathrm{ln} \mathrm{S}+51.4$ & 0.968 & $-0.305 / \mathrm{S}$ \\
\cline { 2 - 6 } & Thickness & $\mathrm{T}=41.784 \mathrm{~S}^{-0.0098}$ & 0.996 & $-0.367 \mathrm{~S}$ \\
\hline \multirow{3}{*}{$\mathbf{3} \mathbf{m}$} & Length & $\mathrm{LI}=-0.001 \mathrm{ST}^{2}-0.001 \mathrm{~S}+69.7$ & 0.944 & $-0.001 \mathrm{~S}-0.001$ \\
\cline { 2 - 6 } & Width & $\mathrm{WI}=-0.006 \mathrm{ST}^{2}+0.006 \mathrm{~S}+50.1$ & 0.917 & $-0.0012 \mathrm{~S}+0.0064$ \\
\cline { 2 - 6 } & Thickness & $\mathrm{TI}=-0.0006 \mathrm{~S}^{2}+0.01 \mathrm{~S}+50.098$ & 0.917 & $-0.0012 \mathrm{~S}+0.0064$ \\
\hline \multirow{3}{*}{$\mathbf{6} \mathbf{m}$} & Length & $\mathrm{L}=-0.0006 \mathrm{~S}^{2}+0.002 \mathrm{~S}+73.8$ & 0.975 & $-0.0012 \mathrm{~S}+0.002$ \\
\cline { 2 - 6 } & Width & $\mathrm{W}=-0.0007 \mathrm{~S}^{2}+0.014 \mathrm{~S}+52.4$ & 0.911 & $-0.0014 \mathrm{~S}+0.014$ \\
\cline { 2 - 6 } & Thickness & $\mathrm{T}=-0.0008 \mathrm{~S}^{2}+0.019 \mathrm{~S}+42.5$ & 0.917 & $-0.0016 \mathrm{~S}+0.019$ \\
\hline
\end{tabular}

Table 2: Regression equations derived for the relationship between storage duration (S) and potato basic dimensions of diamont variety

\begin{tabular}{|l|l|l|l|l|}
\hline Height & Property & Equation & $\mathbf{R}^{\mathbf{2}}$ & Change rate, $\mathbf{d D} / \mathbf{d t}$ \\
\hline \multirow{3}{*}{$\mathbf{0 ~ m}$} & Length & $\mathrm{L}=3 \mathrm{E}-05 \mathrm{~S}^{2}-0.043 \mathrm{~S}+64.7$ & 0.999 & $0.00006 \mathrm{~S}-0.04$ \\
\cline { 2 - 6 } & Width & $\mathrm{W}=-0.0003 \mathrm{~S}^{2}-0.031 \mathrm{~S}+52.3$ & 0.995 & $-0.0006 \mathrm{~S}-0.03$ \\
\cline { 2 - 6 } & Thickness & $\mathrm{T}=3 \mathrm{E}-05 \mathrm{~S}^{2}-0.041 \mathrm{~S}+44.4$ & 0.999 & $0.00006 \mathrm{~S}-0.04$ \\
\hline \multirow{3}{*}{$\mathbf{~ m}$} & Length & $\mathrm{L}=0.0004 \mathrm{ST}^{2}-0.0485 \mathrm{~S}+60.3$ & 0.989 & $0.0008 \mathrm{~S}-0.0485$ \\
\cline { 2 - 6 } & Width & $\mathrm{W}=-0.0002 \mathrm{~S}^{2}-0.054 \mathrm{~S}+52.1$ & 0.915 & $-0.0004 \mathrm{~S}-0.0548$ \\
\cline { 2 - 6 } & Thickness & $\mathrm{T}=-0.0009 \mathrm{~S}^{2}-0.014 \mathrm{~S}+44.6$ & 0.897 & $-0.0018 \mathrm{~S}-0.0136$ \\
\hline \multirow{3}{*}{$\mathbf{6} \mathbf{m}$} & Length & $\mathrm{L}=0.0006 \mathrm{ST} \mathrm{T}^{2}-0.072 \mathrm{~S}+60.3$ & 0.995 & $0.0012 \mathrm{~S}-0.07$ \\
\cline { 2 - 6 } & Width & $\mathrm{W}=-0.898 \ln (\mathrm{S})+53.3$ & 0.991 & $-0.8983 / \mathrm{S}$ \\
\cline { 2 - 6 } & Thickness & $\mathrm{T}=-0.67 \ln (\mathrm{S})+45.4$ & 0.989 & $-0.67 / \mathrm{S}$ \\
\hline
\end{tabular}




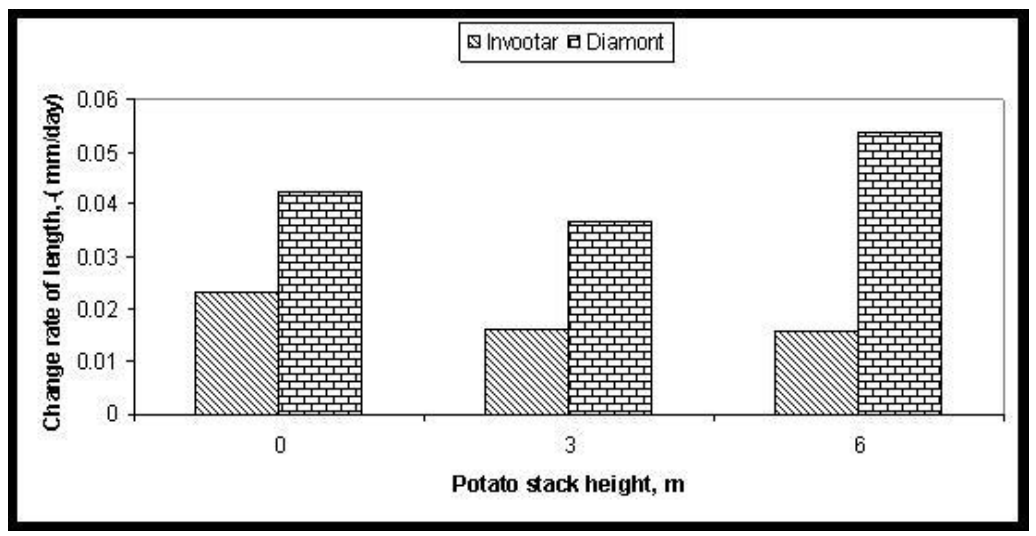

(a)

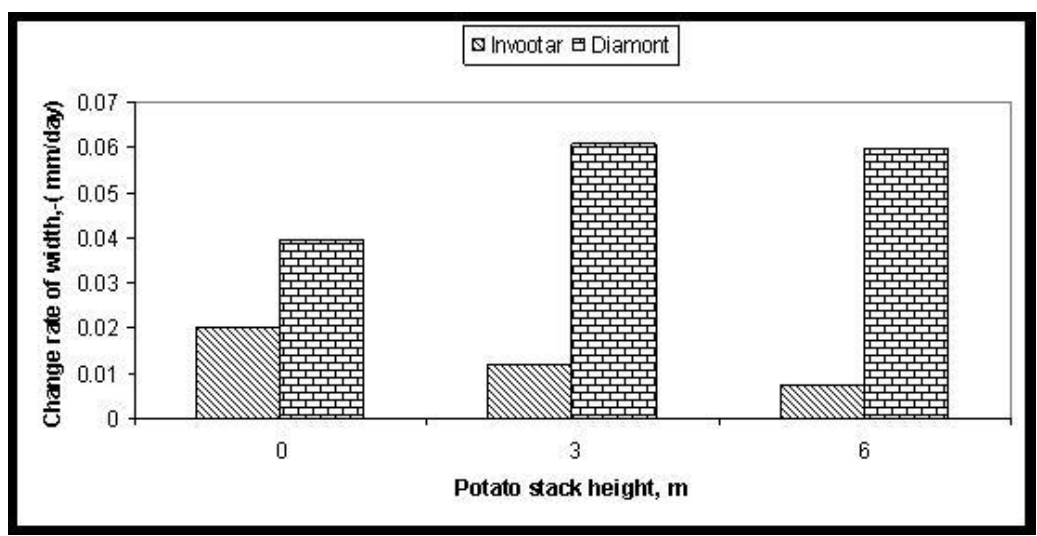

(b)

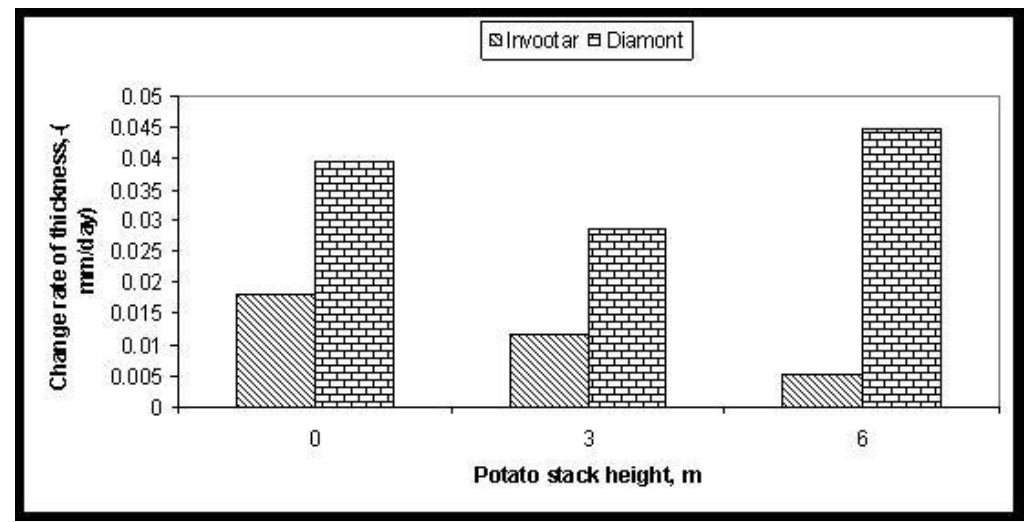

(c)

Fig.4 Effects of stacks height on the change rate of length, width and thickness of potato tubers for both diamond and invootar varieties 


\section{Effects of stacks height and storage duration on potato surface area}

Surface area of potato tuber is considered one of the most commonly used indicator of potato tubers quality. Fig. $5 \mathrm{a}$ and $\mathrm{b}$ illustrates the relationship between storage duration and potato surface area at various stacks heights. The results showed a consistent decrease in potato surface area with increasing storage duration. Surface area of potato tubers was greatly affected by both storage duration and stacks height of potato since the highest values were recorded at the beginning of storage with $6 \mathrm{~m}$ stacks height followed by $3 \mathrm{~m}$ while the minimum values of surface area were recorded at 60 days storage duration with $0 \mathrm{~m}$ stack height treatments.

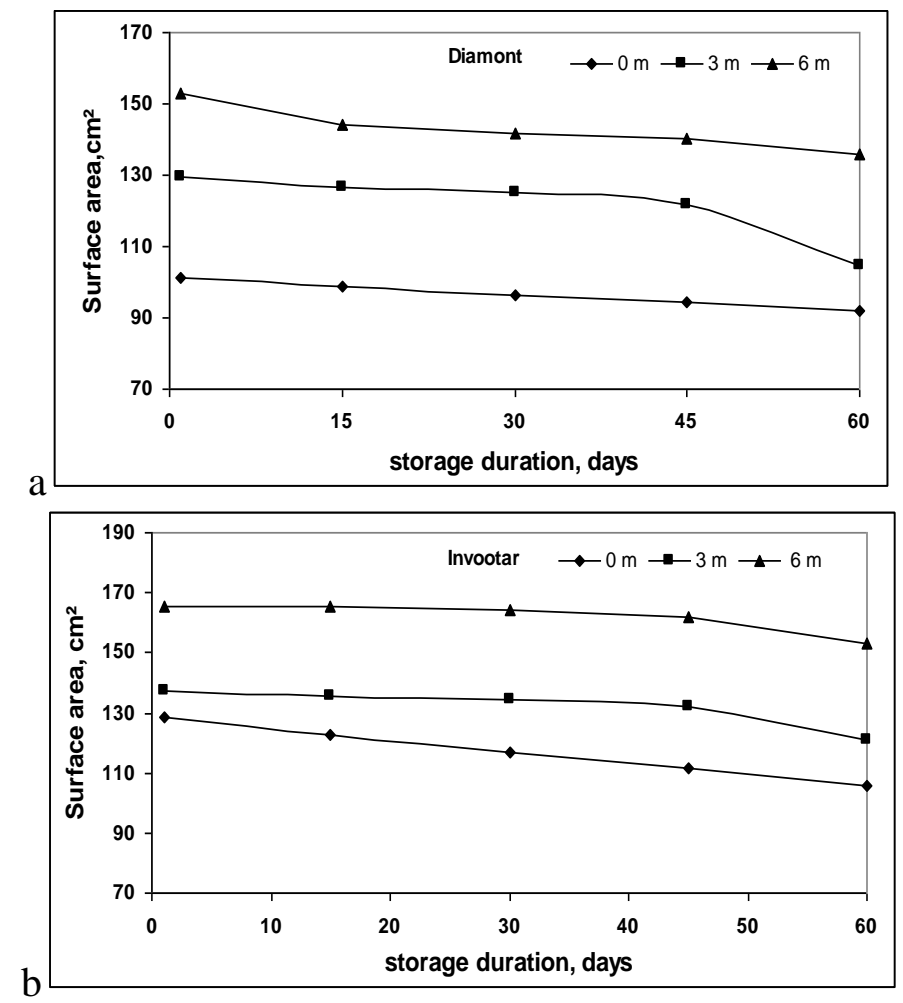

Fig. 6 Effect of storage duration and different stacks heights on surface area of potato tubers for both investigated varieties

Effects of stacks height and storage duration on moisture loss of potato tubers

The weight loss was inversely proportional with storage time as detailed in Table 3. Potato tubers lose weight when stored in an atmosphere not 
saturated with water vapor resulting in relative humidity ranged from 70 to $75 \%$ air indoor refrigerator. This obvious because the potato tuber skin behaves as a membrane through which water, and oxygen, carbon dioxide, etc., may diffuse. The physical weight loss is mainly a result of water evaporation, which depends in part on the diffusivity of water through the skin, the partial pressure of water vapor in the storage air, and the velocity of air circulation around the stored tubers.

Potato tubers with living cells and active enzyme systems may lose weight because of biological processes such as sprouting and respiration. This loss will be added to the loss by evaporation and will be influenced by the biological activities of tubers. The obtained results demonstrated that after 15 days storage the rate of weight loss for diamond variety was higher than invootar variety. The weight loss percentages for diamont variety were $6.20,6.45$ and $5.94 \%$ at 6,3 and $0 \mathrm{~m}$, respectively. The weight loss percentages for invootar variety were 1.6, 1.9, and $9.6 \%$ at 6 , 3 and $0 \mathrm{~m}$, respectively. These above mentioned results means that invootar variety have a little variations in moisture loss over storage period in all treatments except $0 \mathrm{~m}$ stack height the moisture loss values were $9.61,5.5,5.8$ and $0.01 \%$ at $15,30,45$ and 60 storage duration, respectively.

Table 3 effects of stacks height and storage duration on moisture loss of potato tubers

\begin{tabular}{|c|c|c|c|c|c|c|c|}
\hline \multirow{3}{*}{ variety } & \multirow{3}{*}{$\begin{array}{l}\text { Storage } \\
\text { duration, } \\
\text { days }\end{array}$} & \multicolumn{6}{|c|}{ Stacks height, m } \\
\hline & & \multicolumn{2}{|c|}{ 0 } & \multicolumn{2}{|c|}{3} & \multicolumn{2}{|c|}{6} \\
\hline & & mass & $\%$ & mass & $\%$ & mass & $\%$ \\
\hline \multirow{4}{*}{ Diamont } & 15 & 0.20 & 5.9 & 0.215 & 6.45 & 0.21 & 6.2 \\
\hline & 30 & 0.09 & 2.9 & 0.065 & 2.15 & 0.00 & 0.0 \\
\hline & 45 & 0.06 & 2.5 & 0.025 & 1.0 & 0.04 & 1.4 \\
\hline & 60 & 0.01 & 0.01 & 0.09 & 3.15 & 0.11 & 3.5 \\
\hline \multirow{4}{*}{ Invootar } & 15 & 0.33 & 9.6 & 0.06 & 1.90 & 0.05 & 1.6 \\
\hline & 30 & 0.16 & 5.5 & 0.02 & 0.70 & 0.03 & 1.1 \\
\hline & 45 & 0.16 & 5.8 & 0.03 & 1.00 & 0.02 & 0.01 \\
\hline & 60 & 0.01 & 0.01 & 0.02 & 0.85 & 0.02 & 0.76 \\
\hline
\end{tabular}




\section{Effect of potato stacks height on Temperature of potato stacks throughout 24 hrs}

Temperature was recorded hourly to plot it in different cases of stacks height. Figure 6 illustrates that temperature decreases gradually with increasing potato stack height which may have been a result of good air movement through potato stacks. Additionally this is due to the fact that in a well ventilated cold store, cold air can go through a larger exposition area of the stack and take heat out of the stack and thus decrease the average temperature of the product (potato). $3 \mathrm{~m}$ stack height produced medium temperatures between 0 and $6 \mathrm{~m}$ height which is reasonable height in the economical point of view. As shown in the figure the outside temperature is comparable to the temperature inside the cold store. Other studies showed that the stack dimension has a greater influence on the average temperature of potato in comparison to stack size over the period of transient cooling. The figure further shows the difference between temperature inside and outside (os) the clod store.

The results therefore suggest that choosing the optimum storage conditions in terms of stacks height and/or stacks dimensions can keep the average temperature around and in between stacks at an optimum values that keep tubers properties in a good condition and thus good quality. Keeping potato tubers with good quality ends up with high total return.

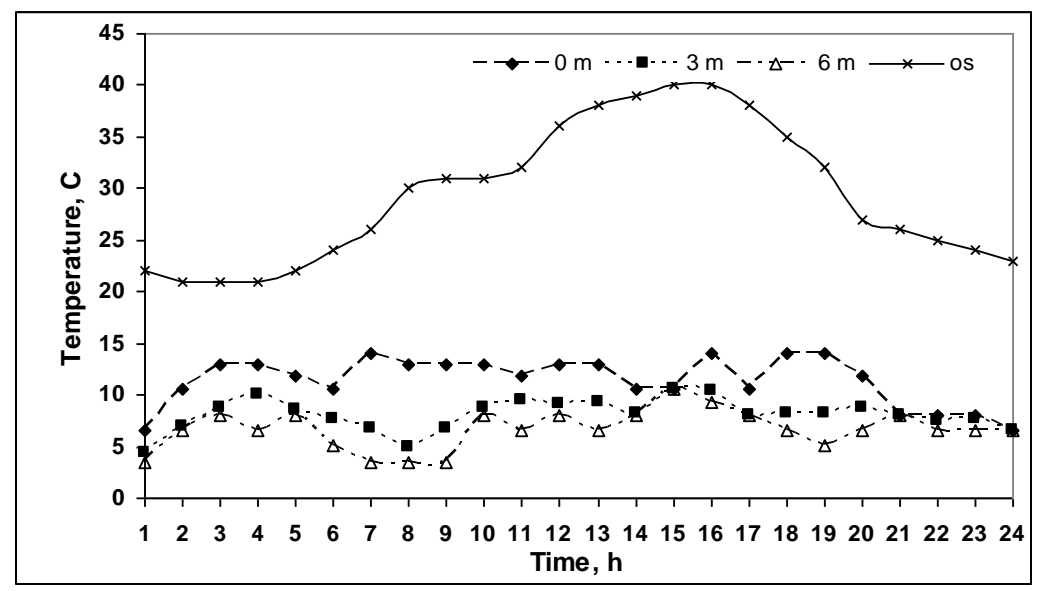

Fig. 6 Effect of different stacks heights on temperature of potato stacks throughout the day 


\section{Effect of potato stacks height on and enthalpy}

Enthalpy values decreased with increasing potato stacks height since greater values were obtained with $0 \mathrm{~m}$ stack height and lower values were recorded with $6 \mathrm{~m}$ stack height. Enthalpy decreased by 6 and $8 \%$ when stack height increased from 0 to $6 \mathrm{~m}$ for diamond and invootar respectively. Figure 7 depicts the effects of stack height on enthalpy source of both potato varieties. As seen in the figure enthalpy values in case of diamont variety were less affected by stacks height. Because of high labor cost and low difference between 3 and $6 \mathrm{~m}$ stacks height, $3 \mathrm{~m}$ would be the optimum. Furthermore, it is better to store diamond variety at low heights since it is greatly affected by stacks height and therefore ensure good air movement and thus cooling for potato stacks.

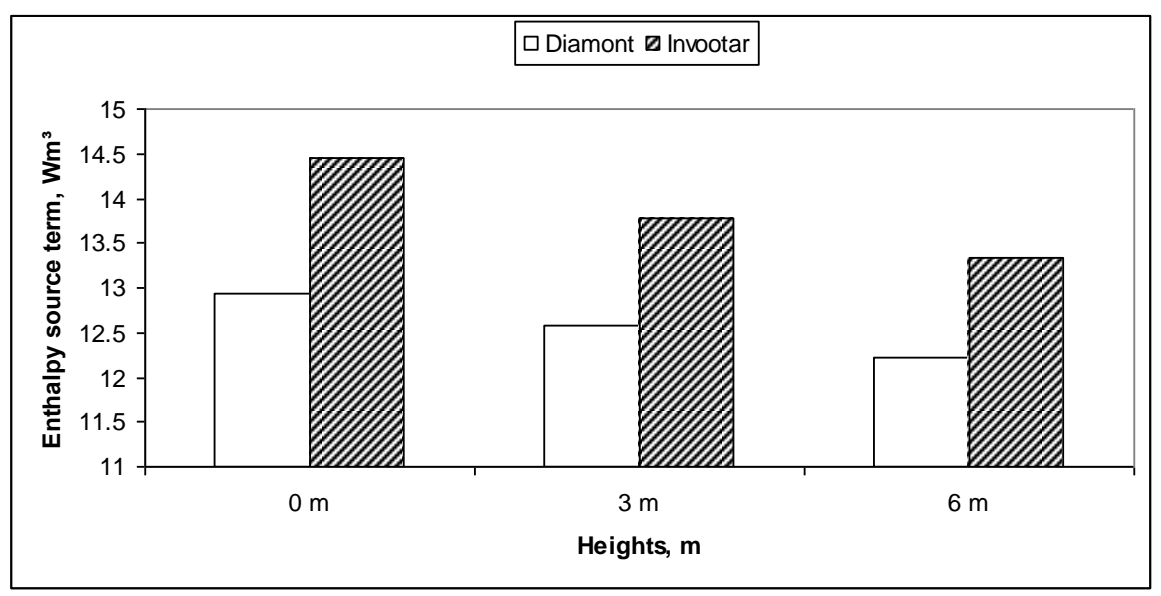

Fig. 7 Effect of different stacks heights on enthalpy of potato stacks for both diamond and invooter

\section{CONCLUSION}

This research based on the hypothesis that high potato tubers quality can be achieved by choosing the proper storage conditions. It can be concluded that increasing potato stacks height enhances potato tubers quality. The results demonstrated that the change rate in basic dimensions (length, width and thickness) was higher in diamond variety more that Invootar. The change rate was remarkable at $6 \mathrm{~m}$ stacks height for both varieties. Surface area of potato tubers increased with increasing stacks height and decreased with storage duration. Temperature within the stacks 
decreased with the treatments at 3 and $6 \mathrm{~m}$ stack height that improved potato quality parameters. The results fundamentally showed that optimum storage conditions including potato stacks height and storage duration can achieve high quality of potato tubers. Potato variety should be taken into account when choosing storage conditions.

\section{REFRENCES}

Brosnan, T. and D. W. Sun (2001). Precooling techniques and applications for horticultural products- a review. International Journal of Refrigeration, 24: 154 -170.

Chourasia, M. K. and T. K. Goswami (2001). Losses of potatoes in cold storage vis-à-vis types, mechanism and influential factors. Journal of Food Science Technology Mysore, 38 (4), 301-313.

Chourasia, M. K.; P. Maji; A. Baskey and T. K. Goswami (2005). Estimation of moisture loss from cooling data of potatoes. Journal of Food Process Engineering, 28: 397-416.

Chourasia, M. K. and T. K. Goswami (2007a). Steady state CFD modeling of airflow, heat transfer and moisture loss in a commercial potato cold store. International Journal of Refrigeration., 30, 672689.

Chourasia, M. K. and T. K. Goswami (2007b). Three dimensional modeling on airflow, heat and mass transfer in impermeable enclosure containing agricultural produce during natural convective cooling. Energy Conversion Management, 48: 2136-2149.

Geankoplis, C. J. (1993). Transport processes and unit operation. New Delhi, India: Prentice Hall of India.

Golmohammadi, A. and A. H. Afkari-Sayyah (2013). Long-Term storage effects on the physical properties of the potato. International Journal of Food Properties, 16: 104-113.

Hoang, M.L.; P. Verboven; M. Baelmans and B.M. Nicolai (2004). Sensitivity of temperature and weight loss in the bulk of chicory roots with respect to process and product parameters. Journal of food Engineering, 62: 233-243.

$\mathrm{Hu}, \mathrm{Z}$. and D. W. Sun (2000). CFD simulation of heat and moisture transfer for predicting cooling rate and weight loss of cooked ham 
during air-blast chilling process. Journal of Food Engineering, 46: 189-197.

Mohsenin, N. N. (1986). Physical properties of plant and animal materials. Gordon and Breach Science Publishers: New York, 742pp.

Nourian, F.; H. S. Ramaswamy and A. C. Kushalappa (2003). Kinetics of quality change associated with potatoes stored at different temperatures. Lebensm. Wiss. U. Technol, 36: 49-65.

Pardo, J. E.; A. Alvarruiz.; J. I. Perez.; R. Gomez and R. Varon (2000).

Physical-chemical and sensory quality evaluation of potato varieties (Solanum tuberosum). Journal of Food Quality, 23 (2): 149-160.

Van't Oostar, A. (1999). Storage of potatoes, In: F. W. Bakker-Arkema (Ed.), CIGR Handbook of Agricultural Engineering. ASAE, vol. IV: 93-125.

Verboven, P.; D. Flick; B. M. Nicolai and G. Alvarez (2006). Modeling transport phenomena in refrigerated food bulks, packages and stacks: basics and advances. International Journal of Refrigeration, 29: 985997.

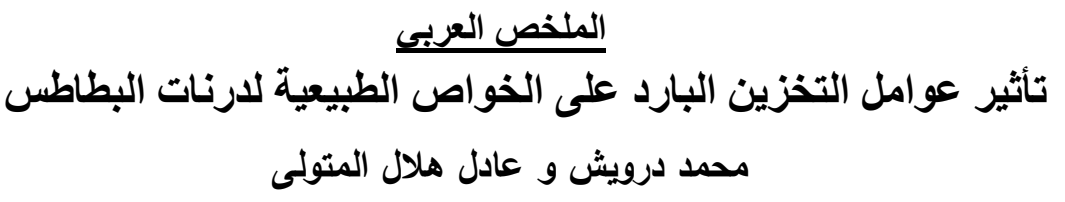

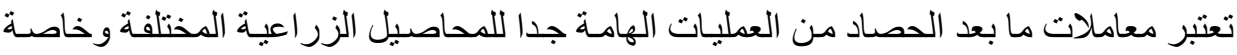

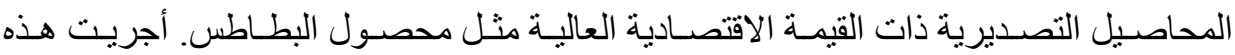

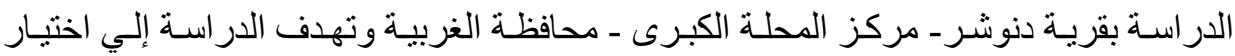

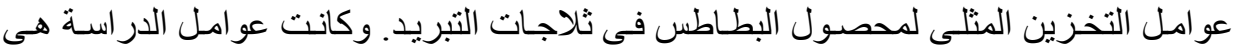

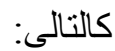

$$
\begin{aligned}
& \text { • صنفين من البطاطس هما دايمونت ـ انفوتر }
\end{aligned}
$$

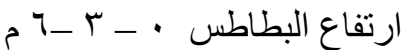

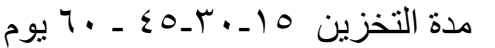

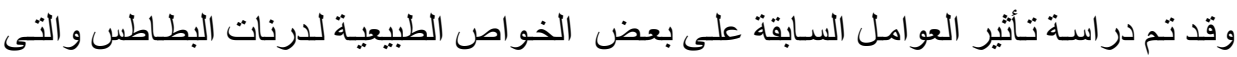

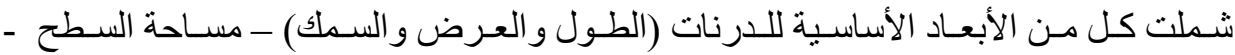

$$
\text { المحتوى الرطوبى - درجة الحر ارة }
$$

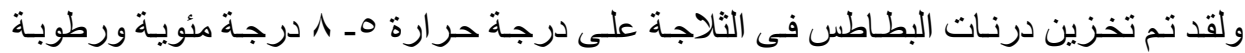

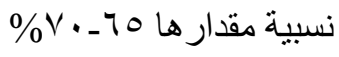

مدرس الهندسة الزراعية ـ قسم الهندسة الزراعية ـ كلية الزراعة ـجامعة طنطا. 


\section{وكانت أهم النتائج المتحصل عليها كالأتي:}

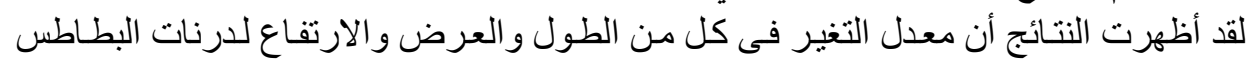

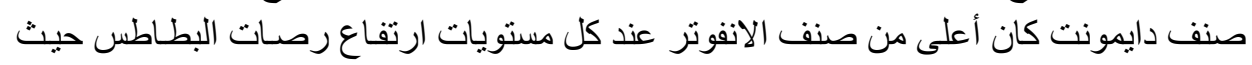

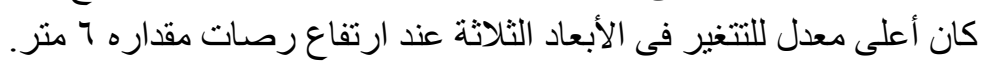
أظهرت قياسـات درجـة الحر ارة لرصـات البطـاطس أن ارتفـاع بام ، جم أدى إلى التبريد الجيد

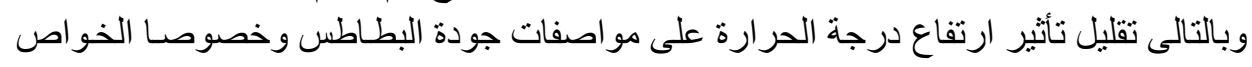

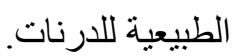

وتوصى الدر اسة باستخدام ارتفاع لرصات البطاطس من ب ـ 7 م و التى تحسن من حركة الهو اء

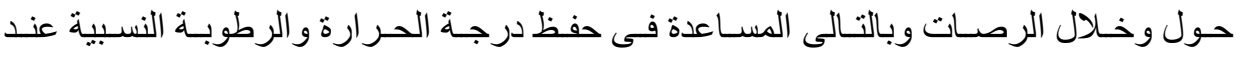

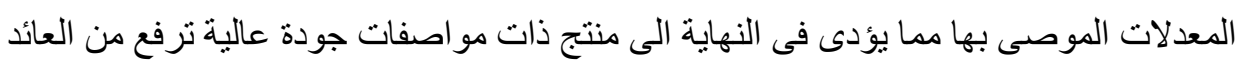

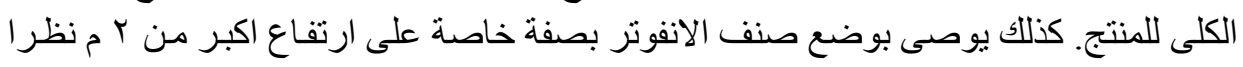

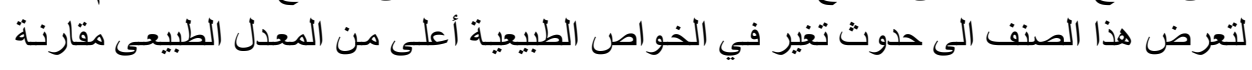
بصنف الدايمونت. 